\title{
THE INFLUENCE OF RESILIENCE AND SUSTAINABILITY PERCEPTION ON AIRPORT BRAND PROMOTION AND DESIRE TO REUSE OF AIRPORT SERVICES: THE CASE OF IRAN AIRPORTS
}

\author{
Mahsa PISHDAR ${ }^{1}$, Fatemeh GHASEMZADEH ${ }^{2}$, \\ Lijana MASKELIÜNAITÉ ${ }^{3}$, Justas BRAŽIŪNAS ${ }^{4}$ \\ ${ }^{1,2}$ Faculty of Management and Accounting, Allameh Tabataba'i University, Tehran, Iran \\ ${ }^{3,4}$ Dept of Mobile Machinery and Railway Transport, Vilnius Gediminas Technical University, Vilnius, Lithuania
}

Received 17 December 2017; revised 30 December 2017; accepted 5 May 2018

\begin{abstract}
Sustainability and resilience are important in social, economic and environmental aspects. However, inspections show that in developing countries like Iran, sustainability and resilience strategies lose their significance when economic problems and high workload come to matter. This research tries to determine what factors encourage managers to consider airport sustainability in long-term and different situations. Such investigations are essential for a developing country like Iran, which has 54 airports under a central management system, which can help deploying selected strategies. Results of this study show that if passengers perceive the sustainability activities and ethical cores of an airport, they consider it more prestigious and become willing to reuse airport services for their future travels. They also turn out as evangelists and changes of the way people travel becomes visible on a wider scale. This can help managers to understand recent travel behaviour of airport passengers and enhance the airports' performance considering different aspects equally, which are profitable for airport system, public and environment as a whole.
\end{abstract}

Keywords: airport reputation, brand evangelism, ethical corporate identity, resilience, sustainability, airport services.

\section{Introduction}

Nowadays, corporate reputation and organizations' ethical core stance can be said to matter more than what the organizations offer (Karaosmanoglu et al. 2016). Corporate reputation makes customers prefer special corporate services when other companies' services are presented at a similar cost and quality. Strong reputation makes the corporate more competitive while weak reputation can quickly harm customer and employees loyalty and even support people's adoption of new travel behaviour (Strömberg et al. 2016; Wang et al. 2016). Airports are not an exception in this domain. Efficient and effective airports have turned out to be fruitful poles. The importance of airports as global business gateways is now completely diagnosed all over the world. Airports play a critical role in people and goods transport in regional, national, and international commerce and have an important role in shaping their travel behaviour (ACRP 2012, 2016). They also can be assumed as the key catalysts for urban growth and economic development in an era of global urbanization (Addie 2014). However, liberalization of the air transport market all over the world has created new dynamics into the aviation. This has put the airport business in a competitive environment and arguably airports' reputation and brand management in this situation become more important than before (Jimenez et al. 2014; Lee, Park 2016).

Although there are various components that can bring corporate reputation to the airports, it should be mentioned that the way, which airports deal with challenges, their capabilities to preserve passengers' security and their efforts toward sustainable transportation as a whole, place them under a magnifying glass of activists and interest groups (Olfat et al. 2016; Piatkowski et al. 2015; Ryley et al. 2013). However, this scrutiny can change consumers' perceptions about airports performance if the promises of airports turn out to be exaggerated or empty (Karaosmanoglu et al. 2016). As a result, it is clear that brand management establishes a stronger voice about airports' competitive advantages and a good reputation can motivate people to advertise its performance.

${ }^{*}$ Corresponding author. E-mail: justas.braziunas@vgtu.lt 
Because of this, international and national airports and all their relevant institutions have been adopting more holistic resilience and sustainability approaches. By doing so, they aim at achieving the full integration of economic viability, operational efficiency, livability, natural resource conservation and social responsibility (Oto et al. 2012).

The delicate point is that nowadays, most of airport managers in different countries are aware of the advantages of taking such approaches, but when the workloads are high and economic problems come to matter, these approaches and their related plans lose their priorities. This situation becomes more obvious in developing countries like Iran, which airports' income receives high importance. This shapes a study gap, since an integrated study has not been found which investigate the effect of resilience and sustainability and ethical identity on airport reputation. It should be determined that what factors encourage managers to consider airport sustainability in long-term and different situations. As a result, this study's aim was to see if passengers comprehend the efforts of managers in making airport more resilience and sustainable, and consider the ethical identity of it important and try to advertise the services. Resilience and sustainability principles can receive ongoing attention in all work situations and the whole community takes advantages in this regard. Therefore, it is worthy to investigate matters that can bring reputation to airports and help them to enhance their competitive advantages in this way. That is why it can be said that such a study is unprecedented and essential and can help airport managers to set suitable strategies in order to receive positive feedback from society. It can also encourage them to spread the airport's capabilities.

Such investigation is crucial for Iran airports too. There are 54 airports in Iran that are under the management of Iran Airports Company. Many of these airports are not profitable and the non-aviation income rate is far less than global rate. Resilience and sustainability concepts and ethical cores are not fully under consideration because of this. That is why if it can be ensured that resilience and sustainability activities or airports' ethics are perceived important by passengers and can shape a positive image in their minds, their positive word of mouth will attract more passengers and enhance financial performance of airports.

The rest of this paper is structured as follows. In Section 1, the literature of corporate reputation, resilience, sustainability, corporate identity and ethical corporate identity and brand evangelism is considered. The research methodology is explained in Section 2 and results of analysis are presented in Section 3. Finally, the last section concludes the paper, including suggestions for further research.

\section{Theoretical background}

\subsection{Airport reputation}

Scholars have well acknowledged that a strong brand has a critical role in bringing long-term competitive advantages to the corporation (Santos-Vijande et al. 2013). Cor- porate reputation is an intangible asset, which can bring stakeholders' supports and their positive word of mouth. Actually, positive word of mouth makes corporate reputation stronger passing the time. This encourages corporations to care more about their reputations (Abimbola 2009; Hong 2008; Ingenhoff, Buhmann 2016; Korda et al. 2012). Reputation can make brand stronger and help the company to achieve its business goals (Fombrun, Van Riel 1997; Schaarschmidt 2016; Wang et al. 2016).

Airports good reputations can bring similar advantages to them too. Airports should not be just a place to wait but should be a place to present more values to stakeholders. Airports can be a place for passengers to have fun while producing non-aviation income at the same time (Castro, Lohmann 2014; Minato, Morimoto 2011). Good reputation can also enhance employees' performance. Schaarschmidt (2016) showed that if front line service employees' perceive external reputation, they will be persuaded to participate in service innovation at airport. In addition, it has been proved that social media, transparency for providing information, and social responsibility have significant influence on airport reputation and can encourage passengers to advertise services (Lee, Park 2016).

Corporations in different industries glorify their brands and reputations as well as their products and services by taking responsibility for well-being of the communities and environments in which they operate $(\mathrm{Oz}-$ dora Aksak 2016; Pohle, Hittner 2008; Saeidi et al. 2015; Shim, Yang 2016). Therefore, the resilience and sustainability principles can affect the preciousness of the corporate reputation.

\subsection{Airport resilience}

Resilience is the capability of a system to observe shocks without major failures or to prevent something bad to become worse, while promoting proper knowledge management in order to learn from experiences and prevent the occurrence of similar events in the future (Woods 2015; Pettersen, Schulman 2019).

In recent years, aviation like other industries is facing with different challenges and its business continuity has been threatened in this way. Airports are not exception and their resilience should be studied in depth. Airports are seen to be vulnerable to unfavourable events such as terrorism, pandemics and climate changes (Carlisle 2015). Since airports are frequently constructed in coastal areas, critical climate change risks like rising sea levels and resonant rainfall patterns are observant (Graham 2016). In addition, rapid changes in consumer needs and technologies are creating a situation in which corporations should increasingly expect dynamics in their business models. While often perceived as an operational issue, resilience is an increasing feature of airport business management and determines how airports should evolve their functions to face new challenges (Carlisle 2015).

Airport resilience means if something unusual occurs and affects the normal operations, airports' managers and staff should be ready in advance to recover the airport in 
the shortest possible time. It must be always ensured that runways, lightening and communication systems are efficient and passengers can be moved smoothly in and out of the airport. These activities can have positive impact on people if they are truly perceived (Graham 2016). Actually, organizational resilience is a key factor to make reputation more strong. Resilience helps organizations to keep trust, good stakeholder perceptions and supportive behaviour (Locke, Ziegler 2016). Clarification of resilience functions in citizens' minds even can make government reputation stronger (Crijns et al. 2017). Therefore, the first hypothesis can be set as such:

- $\mathrm{H}_{1}$ : passengers' positive perceptions about airport attempts toward getting resilient increase airport reputation and their inclination to use airport services.

\subsection{Airport sustainability}

The most famous definition of sustainability goes back to the United Nations (UN) World Commission on Environment and Development (WCED) report called "Our Common Future". Sustainable development is known as a kind of development that meets the needs of the present without compromising the ability of future generations (Banerjee 2002; UN WCED 1987). Since then the sustainable development concept has been evolved and used in various systems such as urban development, agriculture and transportation (Bolcárová, Kološta 2015).

Airport sustainability is about the insurance of the environment protection and conservation of natural resources while considering the needs of airport officials and public simultaneously, obtaining the objective of cognitions economic and employment rate of growth (ACRP 2012, 2016). Because of the importance, different agencies like Federal Aviation Administration (FAA) have considered various programs such as the Noise Compatibility Program and Voluntary Airport Low Emissions Program to help airports achieve sustainability. FAA as like as other agencies believes that airport sustainability will be fulfilled only by consideration of environmental, community, economical and operational goals at the same time (FAA 2019). In long-term, airports with powerful economic structures, which can meet the social needs of stakeholders and minimize negative environmental impacts can be sustainable. In the short term, they should be competitive to sustain economic viability while preserving natural and human resources. These activities can enhance value of airports in people minds (Artiach et al. 2010). In other words, reputations are shaped on the perception that a company will do the right thing, treat its staff correctly, make safe products, perform its obligation and will be well governed. Sustainability drives trust, which in turn drives reputation (3P Contributor 2011). The intensified important link between sustainability and reputation is obvious more than before because of that (Panzone et al. 2016).

Another matter is that today's turbulent world makes it necessary to take a dynamic approach for sustainability analysis. Sustainability performance should be considered in the face of unpredictable disruptions and organizational resilience (Fahimnia, Jabbarzadeh 2016). Resilience can be helpful in shaping sustainability. Resilience makes it possible to pass the challenges and ensures business continuity in this way and has received a lot of attentions nowadays by itself (Derissen et al. 2011). So, the effect of resilience activities on passengers is considered separately from the concept of sustainability because of its importance. The second and third hypothesis of this study is set as such:

$-\mathrm{H}_{2}$ : passengers' comprehension of airport's resilience makes them consider airport more sustainable;

- $\mathrm{H}_{3}$ : passengers' perception about airport sustainability can enhance airport reputation.

\subsection{Ethical corporate identity}

There is no single definition for the corporate identity (Balmer 2014; Hatch, Yanow 2008). However, corporate identity can be considered as a visual appearance of the brand values that are considered by senior managers to represent the discerned characteristic of the corporation (Rodrigues, Child 2008). Corporate identity is also defined as a specified general feature that could make interactions with stakeholders and structure the way they cooperate in different affairs (Cornelissen et al. 2007). So, corporate identity can be considered as a strategic activity, which utilizes some signs for introducing the corporate to the stakeholders. Corporate identity is not just made by corporate itself, but the way that corporate interacts with other corporations can also construct its identity (Hildebrand et al. 2011; Dinnie 2009). London Luton Airport for instance was designed to be a more efficient and passenger focused one, so that makes passengers experience pleasant and the staff be proud of. This positive intention can turn passengers or staff into brand ambassadors or evangelists (ICO 2015; Kim 2014).

Various components determine corporate identity. Van Riel and Van den Ban (2001) considered identity mix consisted of the employees' behaviours, symbolism, corporate social relationships and corporate self-belief. However, from the Aaker (2004) and Bartholmé, Melewar (2011) points of view, innovation is the greatest subject that should be investigated in determination of corporate identity. When the innovation is understandable and relevant, it could give the corporation a special identity. Corporate should determine where it is located in the competiveness sphere before taking any decisions.

It is also notable that ethical principles control the relationships between the corporate and society and should be under consideration because of this. Ethical corporate identity contains informational worth and enhances stakeholders' satisfaction about the corporation performance (Said et al. 2013). That is why ethical corporate identity can reduce the customers' scepticism toward corporate strategies. Ethical corporate identity provides a comprehensive approach that is essential for connecting what the 
company has and what outsiders perceive about parts of the corporate identity (Balmer et al. 2007).

Hence, it is obvious that if people see corporate as an ethical identity, they put more values on airports' efforts toward resilience and sustainability concepts. This can be helpful in making good corporate reputation (Karaosmanoglu et al. 2016). All of these are essential in transportation systems as like as other systems (Paliderova et al. 2015). That is why it can be presumed that (fourth and fifth hypothesis):

$-\mathrm{H}_{4}$ : the relationship between airport resilience activities and its reputation is moderated by the ethical corporate identity in so far as passengers put more value toward the activities of an airport that clarifies its ethical stance;

- $\mathrm{H}_{5}$ : the relationship between airport sustainability and its reputation is moderated by ethical corporate identity in so far as passengers consider more worth toward the activities of an airport that express its ethical position.

\subsection{Brand evangelism}

It is a fact that when customers are excited about a corporate product or service, they truly become evangelists of the corporation. These customers who are also called brand ambassadors willingly put ample energy into expansion of the corporate market (Huba, McConnell 2012). Their positive word-of-mouth and support of the company's brand bring many advantages such as reduction in the cost of advertising. Evangelism marketing is more commonly known as word of mouth marketing and is based on customers to transfer marketing messages to other potential customers (Marketing Schools 2019). In today's world, word of mouth provides trust in brands more effectively than any other marketing method (Wong 2013; Xiong et al. 2013). That is why nowadays corporations are focusing on those groups of customers that are called evangelists. These people have a great interest in the brand and actively engage in the conveyance of their positive experiences to others. Therefore, evangelism is explaining to the world how a product or service can improve people's lives (Kawasaki 2015; Rehmet, Dinnie 2013).

This matter is important in directing airports too. Social media equips anyone to not only engage with the corporate brand, but also to represent it. Therefore, airport directors should become a brand evangelist equipper and make relationships with brand friends online or offline in order to direct the general mentality in the right way (The Quotient Group 2019). Such an evangelism network produces proud and committed passengers (Rehmet, Dinnie 2013). Therefore, it is logical to presume that (sixth hypothesis):

$-\mathrm{H}_{6}$ : when passengers consider more reputation for an airport, they will be more willing to become evangelists and share their positive experiences with others in order to encourage them to use airport services.

\section{Research methodology}

This paper's aim was to have a practical use of some important and novel concepts with the descriptive survey research method in order to figure out some of the components that can bring reputation to the airports and cause people to become evangelists. Based on mentioned studies in Section 2, this study uses resilience as independent variable, sustainability and corporate reputation as mediating variables and brand evangelism as a dependent variable while ethical corporate identity plays the role of a moderating variable. The survey was conducted from September till December 2016 and the measurement was done by use of questionnaire. The questions were developed by studying related literature.

Statistical sample in this study is constituted from passengers of 13 Iranian airports with the highest passenger traffic like Mehrabad Airport, Imam Khomeini Airport, Mashhad Airport and Tabriz Airport. By consideration of Cochran's sample size formula for unlimited population and taking 90\% confidence level and 7\% error level, 139 passengers from each under investigation airport are selected randomly. As for the method of filling out questionnaires, the passengers filled out the questionnaires themselves through online submissions or on paper. The total number of returned questionnaires was 1730, and after excluding 23 questionnaires with insufficient responses, 1707 questionnaires were used for final analysis. These passengers have the experience of air travel from 2014 till 2016 to the developing countries in Asia, such as Iraq and Pakistan, and the result of this study can reflex the situation in these countries of the area too.

Demographics of the sample are observable in Table 1 . The gender ratio of the respondents showed that more males participated, with 1323 males (75\%) and 441 females $(25 \%)$ participating. Considering age of the respondents, it becomes clear that people in their 50s have

Table 1. Demographics of the sample

\begin{tabular}{|l|l|c|}
\hline Variable & \multicolumn{1}{|c|}{ Group } & \% frequency (No) \\
\hline \multirow{4}{*}{ Gender } & man & $0.750(1280)$ \\
\cline { 2 - 3 } & woman & $0.250(427)$ \\
\hline \multirow{4}{*}{ Age } & $20 \ldots 30$ & $0.062(106)$ \\
\cline { 2 - 3 } & $31 \ldots 40$ & $0.250(427)$ \\
\cline { 2 - 3 } & $41 \ldots 50$ & $0.062(106)$ \\
\cline { 2 - 3 } of education & $51 \ldots 60$ & $0.625(1068)$ \\
\cline { 2 - 3 } & BSc & $0.375(640)$ \\
\cline { 2 - 3 } The use & PhD & $0.375(640)$ \\
\hline \multirow{4}{*}{\begin{tabular}{l} 
of airport \\
\cline { 2 - 3 }
\end{tabular}} & at least once a month & $0.250(427)$ \\
\cline { 2 - 3 } & at least every three months & $0.157(269)$ \\
\cline { 2 - 3 } & at least every six months & $0.263(450)$ \\
\cline { 2 - 3 } & at least once a year & $0.105(179)$ \\
\cline { 2 - 3 } & once in the past few years & $0.210(359)$ \\
\hline
\end{tabular}


most travelled by airplane. As for the level of education, the majority of the respondents have bachelor and master degrees. As for the use of airport, most passengers had travelled at least every three months or once in the past few years through the airports under consideration. As a result of examination of demographic characteristics of respondents, it is clear that they are suitable for making such investigations about airports.

To develop measurements for airport resilience, airport sustainability, ethical corporate identity, airport reputation and brand evangelism, the paper went through the following steps. At first, the previous literature was studied and the concepts were defined in order to bring clarification. In the second step, the measurement items were developed based on literature review. In the third step, the measurement items were purified by asking academic and industrial experts' opinions (three professors and 4 manager of Iranian Airport Holding Company) and questionnaire's content validity was verified in this way. In the fourth step, data was collected by use of developed questionnaire. The main survey was done by taking passengers' opinions. At last, the data collected was analysed. Therefore, the questionnaire was developed through mentioned steps with 20 items (Table 2). A 5-point Likert scale was used ranging from "strongly disagree" to "strongly agree". The measurements that were used in this study can be divided into five groups of airport resilience, airport sustainability, ethical corporate identity, airport reputation and brand evangelism. As is obvious in Table 3, the reliability of each group was above $\alpha=0.7$. Therefore, the developed questionnaire has a suitable reliability too. Operational definitions and measurement items can be seen in Table 2 .

For analysing the data and testing the study's hypotheses, Partial Least Squares Structural Equation Modelling (PLS-SEM) is used. PLS-SEM, which has been determined as a semi-standard statistical method in social sciences determines coefficients in a way that the model can predict the final dependent variables with high degree of reliability and validity. Furthermore, PLS-SEM method estimates all the existing relations in the model, namely the interactions between each of the latent variables and also the weight of all measurable indicators related to these variables (coefficients out of the measuring model) (Ratzmann et al. 2016; Schubring et al. 2016).

The first step for analysing the Structural Equations Model (SEM) is to define a model, which is in fact a combination of structural model and reference model. To investigate direct and indirect causal relationships among these variables, the following reflective conceptual research model is designed that is shown in Figure 1.

\section{Analysis and discussion}

A dimensionality test was performed to investigate sampling adequacy. To measure sampling adequacy, KaiserMeyer-Olkin (KMO) index was used with 0.7 reference value (Lee, Park 2016). Calculated KMO index was 0.746 , which proves that the sample size is adequate.
Smart-PLS software v.3.20 (https://www.smartpls.com) was applied to explore the hypotheses of this study. Before that, measures for checking reliability and validity of the model have been determined and the related results are shown in Table 3. Internal consistency, convergent validity, and discriminant validity were evaluated. For these, Cronbach's alpha $(\alpha)$, Composite Reliability (CR), correlations, and Average Variance Extracted (AVE) were calculated and analysed (Tables 3 and 4).

Cronbach's alpha was considered to evaluate internal consistency. Results of the analysis showed high internal consistency, since all Cronbach's alpha values were more than 0.7 . The results showed Cronbach's alpha value $0.73-$ for airport resilient, 0.86 - for airport sustainability, 0.75 for ethical corporate identity, 0.77 - for airport reputation, and 0.75 - for brand evangelism. After that, convergent validity was evaluated by considering CR. The values of $\mathrm{CR}$ for all the components in Table 3 were more than the base level - 0.7 (Lee, Park 2016).

Goodness of Fit (GOF) was determined with the value of 0.665 . Wetzels et al. (2009) considered GOF values above 0.36 as a sign for a strong goodness of the model fit. Therefore, it can be said that the goodness of current study model fit is strong too.

Factor Loadings (FLs) show the correlations of items with their components. As is shown in Table 3, FL values are high enough and this means that each measurement model is reliable.

Since it is confirmed that the model of this study is reliable and valid and also its GOF is strong, the hypotheses of this study can be investigated. $\beta, t$-value and $R^{2}$ values are shown in Table $5(p<0.05)$.

Path coefficients, which are based on $\beta$ coefficients, were determined by use of Maximum Likelihood Estimator (MLE) to understand the relationship between variables. Table 5 shows overall results. First-of-all, testing results showed that the path coefficient between perceived airport resilience and airport reputation was 1.196. Second, the path coefficient between perceived airport resilience and perceived airport sustainability was 0.976 . Third, the path coefficient between perceived airport sustainability and airport reputation was 0.36 . Fourth, the path coefficient between airport sustainability and brand evangelism was 0.575 . However, path coefficients between ethical corporate identity as a moderator variable and airport reputation from each path related to perceived airport resilience and perceived airport sustainability were negative.

To test the moderation effect of ethical corporate identity in this research model, a significance test was performed using Bootstrapping. Considering $t$-value in Table 5, it is clear that although ethical corporate identity was hypothesized to have a positive moderating effect on the relationship between perceived airport resilience and airport reputation and also between perceived airport sustainability and airport reputation, it was statistically insignificant $\left(\mathrm{H}_{4}\right.$ and $\left.\mathrm{H}_{5}\right)$. Besides, the direct effect of perceived airport resilience on airport reputation was statistically insignificant too $\left(\mathrm{H}_{1}\right)$. However, other hypotheses were statistically confirmed. 
Table 2. Questionnaire items

\begin{tabular}{|c|c|c|c|c|}
\hline $\begin{array}{c}\text { Compo- } \\
\text { nent }\end{array}$ & $\begin{array}{l}\text { Operational } \\
\text { definition }\end{array}$ & Code & Measurement items ${ }^{*}$ & Some related studies \\
\hline \multirow{4}{*}{ 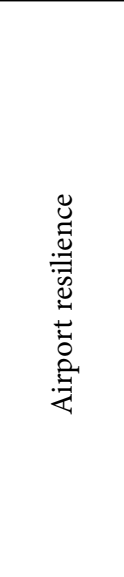 } & \multirow{4}{*}{$\begin{array}{l}\text { Being ready to get } \\
\text { the airport to the } \\
\text { normal operation } \\
\text { again in the shortest } \\
\text { time possible if } \\
\text { something unusual } \\
\text { occurs and affect the } \\
\text { normal operations }\end{array}$} & RE1 & $\begin{array}{l}\text { There is a way such as notifications on the website to understand } \\
\text { that airport management cares about possible crises and has } \\
\text { predicted them. }\end{array}$ & \multirow{4}{*}{$\begin{array}{l}\text { Suárez-Alemán, } \\
\text { Jiménez }(2016) ; \\
\text { Lopez (2016); } \\
\text { Mattsson, Jenelius } \\
(2015) ; \\
\text { ACRP }(2012,2016)\end{array}$} \\
\hline & & RE2 & $\begin{array}{l}\text { I can understand from airport website or any other way of gaining } \\
\text { information that this airport has set plans in order to prevent any } \\
\text { probable crises to happen (crises because of bad weather, terrorism } \\
\text { or any other matter) }\end{array}$ & \\
\hline & & RE3 & $\begin{array}{l}\text { The airport has made it clear that how it has learned from previous } \\
\text { crises and how it wants to prevent their recurrence }\end{array}$ & \\
\hline & & RE4 & $\begin{array}{l}\text { I can see the infrastructures needed for the fastest possible retrieval } \\
\text { when crises happen (infrastructures such as communication routes } \\
\text { to the city, power systems and accessories) }\end{array}$ & \\
\hline \multirow{5}{*}{ 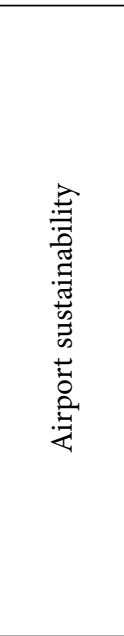 } & \multirow{5}{*}{$\begin{array}{l}\text { Insurance of the } \\
\text { environment } \\
\text { protection and } \\
\text { conservation of } \\
\text { natural resources } \\
\text { while considering } \\
\text { the needs of airport } \\
\text { officials and public } \\
\text { and also economic } \\
\text { objectives }\end{array}$} & SU1 & $\begin{array}{l}\text { Necessary information about airport services or ceremonies and } \\
\text { special activities at airport are announced through means such as } \\
\text { websites or bulletin boards }\end{array}$ & \multirow{5}{*}{$\begin{array}{l}\text { ACRP }(2012,2016) ; \\
\text { SAGA }(2017) ; \\
\text { Lee, Park }(2016) \\
\text { Ferrulli }(2016)\end{array}$} \\
\hline & & SU2 & $\begin{array}{l}\text { The low income people of society have been considered in projects } \\
\text { such as the construction of the dining and setting transportation } \\
\text { systems from the airport to other parts of the system }\end{array}$ & \\
\hline & & SU3 & $\begin{array}{l}\text { Stalls and businesses operating at the airport show that the airport } \\
\text { management is eager to gain non-aviation income and employment } \\
\text { opportunities creation in the region }\end{array}$ & \\
\hline & & SU4 & $\begin{array}{l}\text { Played ceremony, billboards or announcements on the airport's } \\
\text { website show that the airport management cares about the } \\
\text { environment and sustainable development and try to transfer this } \\
\text { culture to others }\end{array}$ & \\
\hline & & SU5 & $\begin{array}{l}\text { Billboards or announcements on the airport's website show that the } \\
\text { airport management pays attention to the areas of humanitarian } \\
\text { activity (such as helping people in times of natural disasters) } \\
\text { importance and tries to promote this culture among the public }\end{array}$ & \\
\hline \multirow{3}{*}{ 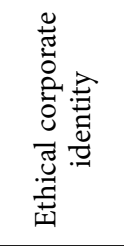 } & \multirow{3}{*}{$\begin{array}{l}\text { Generation of ethical } \\
\text { culture within the } \\
\text { organization and } \\
\text { consideration of } \\
\text { it in the way that } \\
\text { managers cooperate } \\
\text { in different affairs }\end{array}$} & EI1 & $\begin{array}{l}\text { Airport ethical statement is accessible from its website or any other } \\
\text { similar way }\end{array}$ & \multirow{3}{*}{$\begin{array}{l}\text { Karaosmanoglu } \\
\text { et al. (2016); } \\
\text { Akdoğan } \text { et al. } \\
\text { (2016); } \\
\text { Saliani, Eslami } \\
\text { (2016) }\end{array}$} \\
\hline & & EI2 & Airport ethical statement is transparent and comprehensible. & \\
\hline & & EI3 & I myself see the ethical cores of the airport valuable and in process & \\
\hline \multirow{5}{*}{ 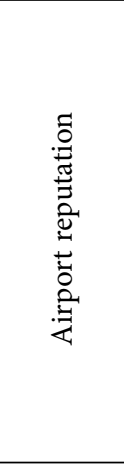 } & \multirow{5}{*}{$\begin{array}{l}\text { Collective judgments } \\
\text { of stakeholders } \\
\text { about an airport } \\
\text { considering its } \\
\text { financial, social } \\
\text { and environmental } \\
\text { impacts over time }\end{array}$} & AR1 & The airport has a good reputation among airports of the country & \multirow{5}{*}{$\begin{array}{l}\text { Kim et al. (2017); } \\
\text { Fracarolli Nunes } \\
\text { Park (2017); } \\
\text { Raj, Babu (2017); } \\
\text { Romano et al. } \\
\text { (2017) }\end{array}$} \\
\hline & & AR2 & $\begin{array}{l}\text { The airport serving process is done decently and in order (services } \\
\text { such as customs, inspection equipment and security guards) }\end{array}$ & \\
\hline & & AR3 & $\begin{array}{l}\text { I believe that airport's managers and staff always look to improve } \\
\text { the serving process }\end{array}$ & \\
\hline & & AR4 & $\begin{array}{l}\text { I believe that airport's staff always seeks to meet the needs of } \\
\text { passengers (the ones such as the need for taking rest and food or } \\
\text { the need to obtain information about the timing of the trip) }\end{array}$ & \\
\hline & & AR5 & $\begin{array}{l}\text { In the airport services planning, how to overcome the needs that } \\
\text { arise in the future (such as increasing the number of passengers, } \\
\text { air traffic in the future and gangs for wide-body aircraft) has been } \\
\text { considered }\end{array}$ & \\
\hline \multirow{3}{*}{ 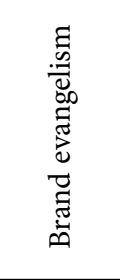 } & \multirow{3}{*}{$\begin{array}{l}\text { The customers who } \\
\text { are willingly put } \\
\text { ample energy into } \\
\text { expansion of the } \\
\text { corporate market }\end{array}$} & BE1 & For the future trips, I will use this airport services again & \multirow{3}{*}{$\begin{array}{l}\text { Cambra Fierro et al. } \\
(2014) ; \\
\text { Islam, Rahman } \\
\text { (2017); } \\
\text { Swimberghe et al. } \\
\text { (2014); } \\
\text { Koll, Wallpach } \\
\text { (2014) }\end{array}$} \\
\hline & & BE2 & I am willing to advertise this airport services to others & \\
\hline & & BE3 & $\begin{array}{l}\text { I encourage others to use this way of trip instead of other ways } \\
\text { such as travelling by train }\end{array}$ & \\
\hline
\end{tabular}

Note: ${ }^{*}$ - a 5-point Likert scale. 


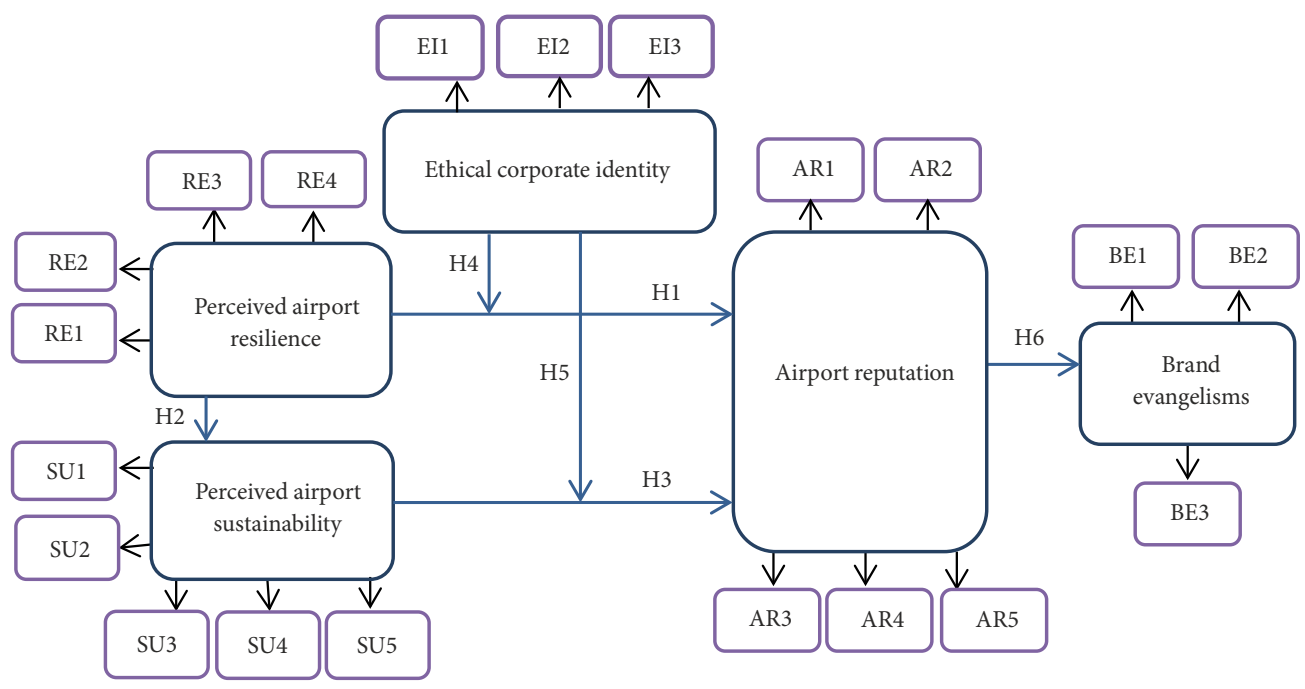

Figure 1. Proposed conceptual model

Table 3. Measures for checking reliability and validity

\begin{tabular}{|c|c|c|c|c|c|}
\hline Component & $\begin{array}{l}\text { Item } \\
\text { code }\end{array}$ & $\mathrm{FL} \geq 0.4$ & $\alpha \geq 0.7$ & $\mathrm{CR} \geq 0.7$ & $\mathrm{AVE} \geq 0.5$ \\
\hline \multirow{4}{*}{$\begin{array}{l}\text { Perceived } \\
\text { airport } \\
\text { resilience }\end{array}$} & RE1 & 0.82 & 0.73 & 0.83 & 0.56 \\
\hline & RE2 & 0.75 & & & \\
\hline & RE3 & 0.84 & & & \\
\hline & RE4 & 0.73 & & & \\
\hline \multirow{5}{*}{$\begin{array}{l}\text { Perceived } \\
\text { airport } \\
\text { sustainability }\end{array}$} & SU1 & 0.91 & 0.86 & 0.90 & 0.66 \\
\hline & SU2 & 0.72 & & & \\
\hline & SU3 & 0.92 & & & \\
\hline & SU4 & 0.80 & & & \\
\hline & SU5 & 0.67 & & & \\
\hline \multirow{3}{*}{$\begin{array}{l}\text { Ethical } \\
\text { corporate } \\
\text { identity }\end{array}$} & EI1 & 0.87 & 0.75 & 0.89 & 0.80 \\
\hline & EI2 & 0.85 & & & \\
\hline & EI3 & 0.91 & & & \\
\hline \multirow{5}{*}{$\begin{array}{l}\text { Airport } \\
\text { reputation }\end{array}$} & AR1 & 0.75 & 0.77 & 0.85 & 0.54 \\
\hline & AR2 & 0.73 & & & \\
\hline & AR3 & 0.81 & & & \\
\hline & AR4 & 0.91 & & & \\
\hline & AR5 & 0.70 & & & \\
\hline \multirow{3}{*}{$\begin{array}{l}\text { Brand } \\
\text { evangelism }\end{array}$} & BE1 & 0.85 & 0.75 & 0.75 & 0.60 \\
\hline & BE2 & 0.41 & & & \\
\hline & BE3 & 0.68 & & & \\
\hline
\end{tabular}

In addition, $R^{2}$ values indicated that 0.953 of the variance in perceived airport sustainability was predictable from perceived airport resilience. 0.84 of the variance in airport reputation was predictable from its independent variables while 0.331 of variance in brand evangelism was predictable from airport reputation. Although the hypothesis related to the effect of airport reputation on brand evangelism was conformed, this relationship should be interpreted more cautious since $R^{2}$ value of path between airport reputation and brand evangelism is not strong.
Table 4. Discriminant validity: AVE values versus crossconstruct squared correlations

\begin{tabular}{|c|c|c|c|c|c|}
\hline 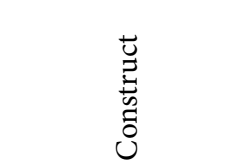 & 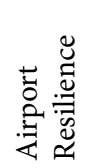 & 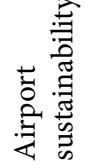 & 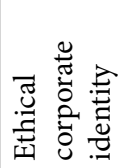 & 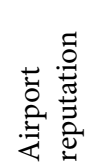 & 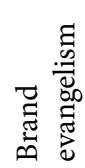 \\
\hline Airport resilience & 0.560 & & & & \\
\hline $\begin{array}{l}\text { Airport } \\
\text { sustainability }\end{array}$ & 0.472 & 0.660 & & & \\
\hline $\begin{array}{l}\text { Ethical corporate } \\
\text { identity }\end{array}$ & 0.232 & 0.251 & 0.800 & & \\
\hline Airport reputation & 0.442 & 0.439 & 0.244 & 0.540 & \\
\hline Brand evangelism & 0.017 & 0.016 & 0.023 & 0.029 & 0.600 \\
\hline
\end{tabular}

It is clear that based on passengers' opinions, efforts of airports management in making it resilient can be helpful in preserving its sustainability and is valuable in this regard. It should also be noted that making efforts in making airports more sustainable will bring more reputation and this reputation can encourage passengers to advertise airport services. The travel behaviour of people can be modified in larger scale because of this.

However, regarding to the $t$-values, it can't be said that ethical corporate identity moderates the relationship between airport resilience and its reputation or the relationship between airport sustainability and its reputation while it is clear that ethical corporate identity can itself affect airport reputation independently. That is why seventh hypothesis $\left(\mathrm{H}_{7}\right)$ is added to the Table 5 .

Another point is that airport resilience and sustainability level in this study is measured based on passengers' preciseness. Passengers consider more reputation for an entity when they perceive its values. So airport managers should try to transfer their values and show efforts toward airport resilience and sustainability to their passengers 
Table 5. Results of hypotheses testing

\begin{tabular}{|l|c|c|c|}
\hline \multicolumn{1}{|c|}{ Hypothesis } & $\beta$ & $t$-value & Test result \\
\hline $\begin{array}{l}\mathrm{H}_{1}: \text { passengers' positive perceptions about airport attempts toward getting resilient } \\
\text { increase airport reputation and their inclination to use airport services }\end{array}$ & 1.196 & -0.420 & not accepted \\
\hline $\begin{array}{l}\mathrm{H}_{2}: \text { passengers' comprehension of airport's resilience makes them to consider airport } \\
\text { more sustainable }\end{array}$ & 0.976 & 13.810 & not rejected \\
\hline $\mathrm{H}_{3}:$ passengers' perception about airport sustainability can enhance airport reputation & 0.360 & 2.460 & not rejected \\
\hline $\begin{array}{l}\mathrm{H}_{4}: \text { the relationship between airport resilience activities and its reputation is moderated } \\
\text { by the ethical corporate identity in so far as passengers put more value toward the } \\
\text { activities of an airport that clarifies its ethical stance }\end{array}$ & -0.187 & 0.021 & not accepted \\
\hline $\begin{array}{l}\mathrm{H}_{5}: \text { the relationship between airport sustainability and its reputation is moderated by } \\
\text { ethical corporate identity in so far as passengers consider more worth toward the } \\
\text { activities of an airport that express its ethical position }\end{array}$ & -0.127 & 0.304 & not accepted \\
\hline $\begin{array}{l}\mathrm{H}_{6}: \text { when passengers consider more reputation for an airport, they will be more willing } \\
\text { to become evangelists and share their positive experiences with others in order to } \\
\text { encourage them to use airport services }\end{array}$ & 0.575 & 7.510 & not rejected \\
\hline $\begin{array}{l}\mathrm{H}_{7}: \text { when passengers consider an ethical identity for the airport they see it more } \\
\text { reputable as a whole }\end{array}$ & 0.145 & 2.065 & not rejected \\
\hline
\end{tabular}

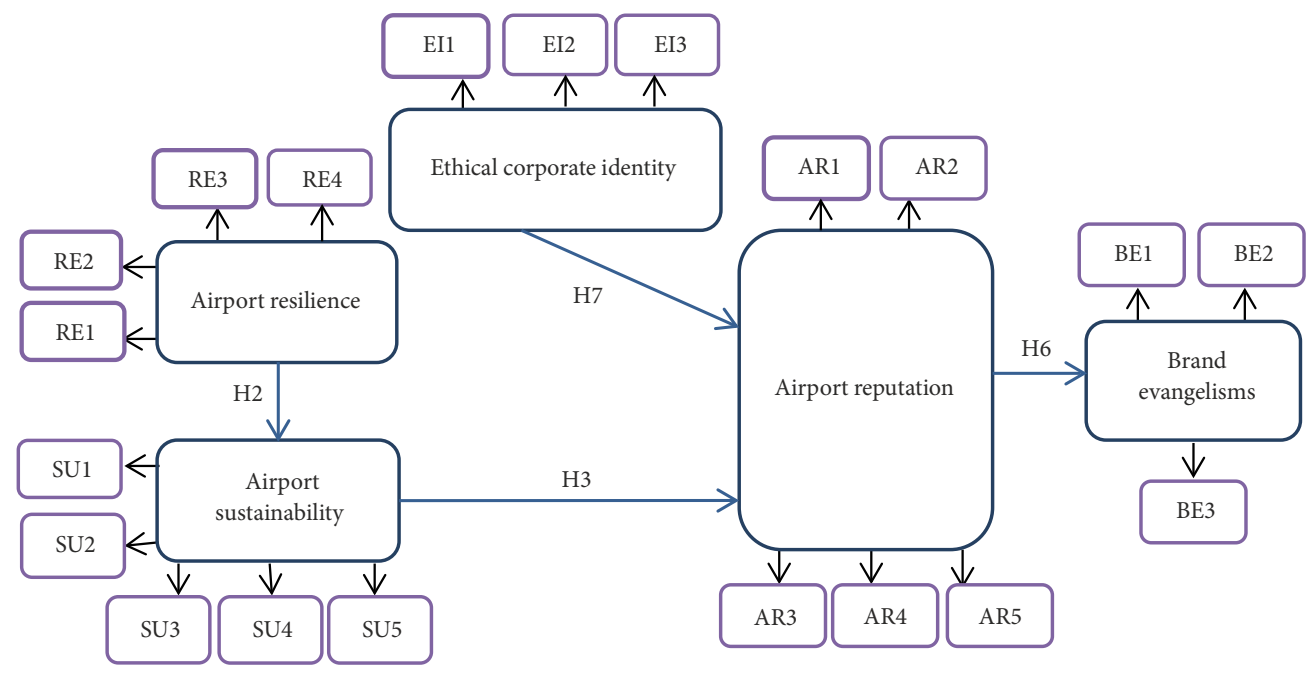

Figure 2. Final conceptual model of this study

and community as a whole. If they do not succeed in encouraging passengers to look at the airport website or do not find a suitable way for information transferring, their efforts will not shape reputation and will not persuade passengers to turn out as brand evangelists. The important matter is what passengers perceive.

According to obtained results, final conceptual model of study is shown in Figure 2.

\section{Conclusions}

Over the past decade, airports role in aviation system has become irrefutable and competition is surely increased in this industry. Airports have to become resilient and sustainable in order to attract social attentions and make significant airline consolidation to be continued. Although the advantages of resilient and sustainable airport for the whole society and also environment have been proved, in many countries especially developing ones like Iran, resilience and sustainability strategies lose their significance when financial matters take place. Because of this, the purpose of this study was to empirically investigate influential relationships between perceived airport resilience, perceived airport sustainability, airport reputation and brand evangelism considering moderating effect of ethical corporate identity. The findings of this study can be summarized as follows. First, perceived airport resilience has been found to have a strong impact on perceived airport sustainability. Second, it became clear that perceived airport sustainability bring more reputation to the airport and as a result, passengers would be more eager to turn out as brand ambassadors. The moderating effect of ethical corporate identity was not statistically confirmed. However, the direct affection of ethical corporate identity on airport reputation has been approved. Third, it has been found that these effects have very high explanatory power 
for airport reputation. The model has explained $84 \%$ of variance in airport reputation. In this regard, this study sets important contributions:

- this study sets a novel bridge between resilience, sustainability and corporate reputation concepts. The results show that airport resilience helps it to become more sustainable and the sustainability of airports brings more reputation to them;

- on the other hand, it became clear that ethical corporate identity can help airports be considered more reputable. This relationship determines the importance of ethics in airports' activities more than before and specifies why ethics should be under consideration by managers in setting plans;

- as is proven, airport reputation can encourage passengers to advertise its services and this can change people travel behaviour as a whole. As previous studies have shown, these self-imposed activities by passengers can bring cost savings and other financial and non-financial advantages. It seems that there is no logical reason to put resilience and sustainability programs away even for a while. This way of thinking about these concepts is unprecedented and essential, since it can help airport managers set proper strategies and develop airports equally considering different economic, social and environmental aspects even in turbulent situations.

That is why it is recommended to the airports' managers to set special plans with determined milestones for pursuing resilience and sustainability programs simultaneously. Besides, responsible staff with specified office must be authorized at airports in order to make it possible to perform resilience and sustainability programs in all the situations.

For the next studies, it is proposed to determine the sustainability efficiency of airports by using techniques such as Data Envelopment Analysis (DEA). Besides, it would be useful to set a conceptual framework for airport resilience or airport sustainability and prioritize the factors. Strategies can be determined based on the importance of airport resilience and sustainability factors in this regard. Probing how to make online airport identity and reputation can be interesting and necessary too. It is clear that social online communication systems and airport website in the simplest possible form can transfer the airport values and its directions considering different social and environmental aspects. Therefore, these ways of communication and the way of transferring the corporate values must be under investigation.

The limitations of this study specify some suggestions for future research too. International airports with different operational characteristics can be an interesting research domain. Comparison of their functions can shape new benchmarking. It was focused on only some of the factors influencing airport sustainability and resilience, considering a variety of factors in next research can be interesting.

\section{References}

3P Contributor. 2011. The Relationship between Reputation, Trust and Sustainable Business. Available from Internet: https:// www.triplepundit.com/story/2011/relationship-between-reputation-trust-and-sustainable-business/75546

Aaker, D. A. 2004. Brand Portfolio Strategy: Creating Relevance, Differentiation, Energy, Leverage, and Clarity. Free Press. 368 p.

Abimbola, T. 2009. Brand, organisation identity and reputation: bold approaches to big challenges, Journal of Brand Management 16(4): 219-220. https://doi.org/10.1057/bm.2008.43

ACRP. 2012. Airport Climate Adaptation and Resilience. Airport Cooperative Research Program (ACRP) Synthesis 33. Transportation Research Board, Washington, DC, US. 96 p. https://doi.org/10.17226/22773

ACRP. 2016. Airport Sustainability Practices - Drivers and Outcomes for Small Commercial and General Aviation Airports. Airport Cooperative Research Program (ACRP) Synthesis 69. Transportation Research Board, Washington, DC, US. 108 p. https://doi.org/10.17226/23486

Addie, J.-P. D. 2014. Flying high (in the competitive sky): conceptualizing the role of airports in global city-regions through “aero-regionalism", Geoforum 55: 87-99. https://doi.org/10.1016/j.geoforum.2014.05.006

Akdoğan, A.A.; Arslan, A.; Demirtaş, Ö. 2016. A strategic influence of corporate social responsibility on meaningful work and organizational identification, via perceptions of ethical leadership, Procedia - Social and Behavioral Sciences 235: 259-268. https://doi.org/10.1016/j.sbspro.2016.11.029

Artiach, T.; Lee, D.; Nelson, D.; Walker, J. 2010. The determinants of corporate sustainability performance, Accounting \& Finance 50(1): 31-51. https://doi.org/10.1111/j.1467-629X.2009.00315.x

Balmer, J. M. T. 2014. Wally Olins (1930-2014), corporate identity ascendancy and corporate brand hegemony. Celebrating the life of Wally Olins: leading corporate identity exponent and prominent brand proponent, Journal of Brand Management 21(6): 459-468. https://doi.org/10.1057/bm.2014.19

Balmer, J. M. T.; Fukukawa, K.; Gray, E. R. 2007. The nature and management of ethical corporate identity: a commentary on corporate identity, corporate social responsibility and ethics, Journal of Business Ethics 76(1): 7-15.

https://doi.org/10.1007/s10551-006-9278-z

Banerjee, S. B. 2002. Organisational strategies for sustainable development: developing a research agenda for the new millennium, Australian Journal of Management 27(1): 105-117. https://doi.org/10.1177/031289620202701S11

Bartholmé, R.; Melewar, T. 2011. Remodelling the corporate visual identity construct: a reference to the sensory and auditory dimension, Corporate Communications: An International Journal 16(1): 53-64. https://doi.org/10.1108/13563281111100971

Bolcárová, P.; Kološta, S. 2015. Assessment of sustainable development in the EU 27 using aggregated SD index, Ecological Indicators 48: 699-705. https://doi.org/10.1016/j.ecolind.2014.09.001

Cambra Fierro, J.; Melero Polo, I.; Sesé Oliván, F. J. 2014. From dissatisfied customers to evangelists of the firm: a study of the Spanish mobile service sector, BRQ Business Research Quarterly 17(3): 191-204.

https://doi.org/10.1016/j.cede.2013.10.001

Carlisle, A. 2015. Business resilience, Airport World: the Magazine of the Airport Council International (1). Available from Internet: http://www.airport-world.com/features/otherarticles/4942-business-resilience.html 
Castro, R.; Lohmann, G. 2014. Airport branding: Content analysis of vision statements, Research in Transportation Business \& Management 10: 4-14.

https://doi.org/10.1016/j.rtbm.2014.01.001

Cornelissen, J. P.; Haslam, S. A.; Balmer, J. M. T. 2007. Social identity, organizational identity and corporate identity: towards an integrated understanding of processes, patternings and products, British Journal of Management 18(1): S1-S16. https://doi.org/10.1111/j.1467-8551.2007.00522.x

Crijns, H.; Cauberghe, V.; Hudders, L. 2017. Terrorism threat in Belgium: the resilience of Belgian citizens and the protection of governmental reputation by means of communication, Public Relations Review 43(1): 219-234. https://doi.org/10.1016/j.pubrev.2016.10.006

Derissen, S.; Quaas, M. F.; Baumgärtner, S. 2011. The relationship between resilience and sustainability of ecological-economic systems, Ecological Economics 70(6): 1121-1128. https://doi.org/10.1016/j.ecolecon.2011.01.003

Dinnie, K. 2009. Taking brand initiative: how companies can align strategy, culture, and identity through corporate branding, Journal of Brand Management 16(7): 496-498. https://doi.org/10.1057/bm.2008.37

FAA. 2019. Airport Sustainability. Federal Aviation Administration (FAA), US Department of Transportation, Washington, DC, US. Available from Internet: https://www.faa.gov/airports/environmental/sustainability

Fahimnia, B.; Jabbarzadeh, A. 2016. Marrying supply chain sustainability and resilience: a match made in heaven, Transportation Research Part E: Logistics and Transportation Review 91: 306-324. https://doi.org/10.1016/j.tre.2016.02.007

Ferrulli, P. 2016. Green airport design evaluation (GrADE) methods and tools improving infrastructure planning, Transportation Research Procedia 14: 3781-3790. https://doi.org/10.1016/j.trpro.2016.05.463

Fombrun, C. J.; Van Riel, C. B. M. 1997. The reputational landscape, Corporate Reputation Review 1(1): 5-13. https://doi.org/10.1057/palgrave.crr.1540008

Fracarolli Nunes, M.; Park, C. L. 2017. Self-claimed sustainability: building social and environmental reputations with words, Sustainable Production and Consumption 11: 46-57. https://doi.org/10.1016/j.spc.2016.04.002

Graham, T. 2016. Adaptable Airports: Designing Resilience. Available from Internet: http://www.aurecongroup.com/en/thinking/insights/airports/adaptable-airports-designing-resilience. aspx

Hatch, M. J.; Yanow, D. 2008. Methodology by metaphor: ways of seeing in painting and research, Organization Studies 29(1): 23-44. https://doi.org/10.1177/0170840607086635

Hildebrand, D.; Sen, S.; Bhattacharya, C. 2011. Corporate social responsibility: a corporate marketing perspective, European Journal of Marketing 45(9/10): 1353-1364.

https://doi.org/10.1108/03090561111151790

Hong, S. Y. 2008. The Effects of Relational Satisfaction, Organizational Reputation, and Identification with Company on Customers' Communication Behaviors. PhD Dissertation. Syracuse University, Syracuse, NY, US. Available from Internet: https://surface.syr.edu/com_etd/9

Huba, J.; McConnell, B. 2012. Creating Customer Evangelists: How Loyal Customers Become a Volunteer Salesforce. Lewis Lane Press. 230 p.

ICO. 2015. London Luton Airport. ICO Design Partners Limited, London, UK. Available from Internet:

https://identitydesigned.com/london-luton-airport

Ingenhoff, D.; Buhmann, A. 2016. Advancing PR measurement and evaluation: demonstrating the properties and assessment of variance-based structural equation models using an example study on corporate reputation, Public Relations Review 42(3): 418-431. https://doi.org/10.1016/j.pubrev.2015.11.010

Islam, J. U.; Rahman, Z. 2017. The impact of online brand community characteristics on customer engagement: an application of stimulus-organism-response paradigm, Telematics and Informatics 34(4): 96-109.

https://doi.org/10.1016/j.tele.2017.01.004

Jimenez, E.; Claro, J.; De Sousa, J. P. 2014. The airport business in a competitive environment, Procedia - Social and Behavioral Sciences 111: 947-954.

https://doi.org/10.1016/j.sbspro.2014.01.129

Karaosmanoglu, E.; Altinigne, N.; Isiksal, D. G. 2016. CSR motivation and customer extra-role behavior: moderation of ethical corporate identity, Journal of Business Research 69(10): 4161-4167. https://doi.org/10.1016/j.jbusres.2016.03.035

Kawasaki, G. 2015. The art of evangelism, Harvard Business Review, May 2015. Available from Internet:

https://hbr.org/2015/05/the-art-of-evangelism

Kim, T. H.; Wu, C.-L.; Koo, T.-R. 2017. Implications of the ageing society and internationalisation for airport services: a perspective on passenger demand for personal space at airport terminals, Journal of Air Transport Management 60: 84-92. https://doi.org/10.1016/j.jairtraman.2017.01.002

Kim, Y. 2014. Strategic communication of corporate social responsibility (CSR): effects of stated motives and corporate reputation on stakeholder responses, Public Relations Review 40(5): 838-840. https://doi.org/10.1016/j.pubrev.2014.07.005

Koll, O.; Wallpach, S. V. 2014. Intended brand associations: do they really drive consumer response?, Journal of Business Research 67(7): 1501-1507. https://doi.org/10.1016/j.jbusres.2013.06.010

Korda, A. P.; Snoj, B.; Žabkar, V. 2012. Antecedents and outcomes of perceived service value: evidence from Slovenia, $E$ \& M Ekonomie a Management 15(1): 105-115.

Lee, Y.-K.; Park, J.-W. 2016. Impact of a sustainable brand on improving business performance of airport enterprises: the case of Incheon international airport, Journal of Air Transport Management 53: 46-53. https://doi.org/10.1016/j.jairtraman.2016.01.002

Locke, L.; Ziegler, M. 2016. How to Build a Stronger Reputation with Trust and Resiliency. Institute for Public Relations, University of Florida, Gainesville, FL, US. Available from Internet: http://www.instituteforpr.org/build-stronger-reputationtrust-resiliency

Lopez, A. 2016. Vulnerability of airports on climate change: an assessment methodology, Transportation Research Procedia 14: 24-31. https://doi.org/10.1016/j.trpro.2016.05.037

Marketing Schools. 2019. Evangelism Marketing: Explore the Strategy of Evangelism Marketing. Available from Internet: http://www.marketing-schools.org/types-of-marketing/evangelism-marketing.html

Mattsson, L.-G.; Jenelius, E. 2015. Vulnerability and resilience of transport systems - a discussion of recent research, Transportation Research Part A: Policy and Practice 81: 16-34. https://doi.org/10.1016/j.tra.2015.06.002

Minato, N.; Morimoto, R. 2011. Designing the commercial sustainability of unprofitable regional airports using system dynamics analysis, Research in Transportation Business \& Management 1(1): 80-90. https://doi.org/10.1016/j.rtbm.2011.06.009

Olfat, L.; Amiri, M.; Bamdad Soufi, J.; Pishdar, M. 2016. A dynamic network efficiency measurement of airports performance considering sustainable development concept: a fuzzy dynamic network-DEA approach, Journal of Air Transport Management 57: 272-290.

https://doi.org/10.1016/j.jairtraman.2016.08.007 
Oto, N.; Cobanoglu, N.; Geray, C. 2012. Education for sustainable airports, Procedia - Social and Behavioral Sciences 47: 1164-1173. https://doi.org/10.1016/j.sbspro.2012.06.795

Ozdora Aksak, E.; Ferguson, M. A.; Atakan Duman, S. 2016. Corporate social responsibility and CSR fit as predictors of corporate reputation: a global perspective, Public Relations Review 42(1): 79-81. https://doi.org/10.1016/j.pubrev.2015.11.004

Paliderova, M.; Bielikova, A.; Spuchlakova, E. 2015. The importance of corporate identity in water transportation company, Procedia Economics and Finance 26: 286-291. https://doi.org/10.1016/S2212-5671(15)00854-0

Panzone, L. A.; Lemke, F.; Petersen, H. L. 2016. Biases in consumers' assessment of environmental damage in food chains and how investments in reputation can help, Technological Forecasting and Social Change 111: 327-337. https://doi.org/10.1016/j.techfore.2016.04.008

Pettersen, K. A.; Schulman, P. R. 2019. Drift, adaptation, resilience and reliability: toward an empirical clarification, Safety Science 117: 460-468. https://doi.org/10.1016/j.ssci.2016.03.004

Piatkowski, D. P.; Krizek, K. J.; Handy, S. L. 2015. Accounting for the short term substitution effects of walking and cycling in sustainable transportation, Travel Behaviour and Society 2(1): 32-41. https://doi.org/10.1016/j.tbs.2014.07.004

Pohle, G.; Hittner, J. 2008. Attaining Sustainable Growth through Corporate Social Responsibility. IBM Global Services, Somers, NY, US. 20 p.

Raj, E. D.; Babu, L. D. D. 2017. An enhanced trust prediction strategy for online social networks using probabilistic reputation features, Neurocomputing 219: 412-421. https://doi.org/10.1016/j.neucom.2016.09.036

Ratzmann, M.; Gudergan, S. P.; Bouncken, R. 2016. Capturing heterogeneity and PLS-SEM prediction ability: alliance governance and innovation, Journal of Business Research 69(10): 4593-4603 https://doi.org/10.1016/j.jbusres.2016.03.051

Rehmet, J.; Dinnie, K. 2013. Citizen brand ambassadors: motivations and perceived effects, Journal of Destination Marketing \& Management 2(1): 31-38.

https://doi.org/10.1016/j.jdmm.2013.02.001

Rodrigues, S.; Child, J. 2008. The development of corporate identity: a political perspective, Journal of Management Studies 45(5): 885-911.

https://doi.org/10.1111/j.1467-6486.2007.00750.x

Romano, A.; Balliet, D.; Wu, J. 2017. Unbounded indirect reciprocity: is reputation-based cooperation bounded by group membership?, Journal of Experimental Social Psychology 71: 59-67. https://doi.org/10.1016/j.jesp.2017.02.008

Ryley, T.; Burchell, J.; Davison, L. 2013. Valuing air transportation and sustainability from a public perspective: evidence from the United Kingdom and the United States, Research in Transportation Business \& Management 7: 114-119.

https://doi.org/10.1016/j.rtbm.2013.03.009

Saeidi, S. P.; Sofian, S.; Saeidi, P.; Saeidi, S. P.; Saaeidi, S. A. 2015. How does corporate social responsibility contribute to firm financial performance? The mediating role of competitive advantage, reputation, and customer satisfaction, Journal of Business Research 68(2): 341-350.

https://doi.org/10.1016/j.jbusres.2014.06.024

SAGA. 2017. Sustainable Principles and Practices. Sustainable Aviation Guidance Alliance (SAGA). Available from Internet: http://www.airportsustainability.org

Said, R.; Daud, M.; Radjeman, L. A.; Ismail, N. 2013. Probing corporate ethical identity of Shariah compliant companies, Procedia Economics and Finance 7: 230-235. https://doi.org/10.1016/S2212-5671(13)00239-6
Saliani, R.; Eslami, H. 2016. Exploring the relationship between ethical climate, reputation and corporate identity (case study of Yazd governor employees), International Journal of $\mathrm{Hu}$ manities and Cultural Studies (1): 416-428.

Santos-Vijande, M. L.; Del Río-Lanza, A. B.; Suárez-Álvarez, L.; Díaz-Martín, A. M. 2013. The brand management system and service firm competitiveness, Journal of Business Research 66(2): 148-157. https://doi.org/10.1016/j.jbusres.2012.07.007

Schaarschmidt, M. 2016. Frontline employees' participation in service innovation implementation: the role of perceived external reputation, European Management Journal 34(5): 540-549. https://doi.org/10.1016/j.emj.2016.02.005

Schubring, S.; Lorscheid, I.; Meyer, M.; Ringle, C. M. 2016. The PLS agent: predictive modeling with PLS-SEM and agentbased simulation, Journal of Business Research 69(10): 46044612. https://doi.org/10.1016/j.jbusres.2016.03.052

Shim, K.; Yang, S.-U. 2016. The effect of bad reputation: the occurrence of crisis, corporate social responsibility, and perceptions of hypocrisy and attitudes toward a company, Public Relations Review 42(1): 68-78.

https://doi.org/10.1016/j.pubrev.2015.11.009

Strömberg, H.; Rexfelt, O.; Karlsson, I. C. M. A.; Sochor, J. 2016. Trying on change - trialability as a change moderator for sustainable travel behaviour, Travel Behaviour and Society 4: 60-68. https://doi.org/10.1016/j.tbs.2016.01.002

Suárez-Alemán, A.; Jiménez, J. L. 2016. Quality assessment of airport performance from the passengers' perspective, Research in Transportation Business \& Management 20: 13-19. https://doi.org/10.1016/j.rtbm.2016.04.004

Swimberghe, K. R.; Astakhova, M.; Wooldridge, B. R. 2014. A new dualistic approach to brand passion: harmonious and obsessive, Journal of Business Research 67(12): 2657-2665. https://doi.org/10.1016/j.jbusres.2014.04.003

The Quotient Group. 2019. 5 Keys to Creating Online Airport Brand Ambassadors. Available from Internet: https://www. thequotientgroup.com/5-key-to-creating-online-airportbrand-ambassadors

UN WCED. 1987. Our Common Future. Report of the United Nations (UN) World Commission on Environment and Development (WCED). 300 p. Available from Internet: http:// www.un-documents.net/our-common-future.pdf

Van Riel, C.; Van den Ban, A. 2001. The added value of corporate logos - an empirical study, European Journal of Marketing 35(3/4): 428-440. https://doi.org/10.1108/03090560110382093

Wang, D. H.-M.; Yu, T. H.-K.; Chiang, C.-H. 2016. Exploring the value relevance of corporate reputation: a fuzzy-set qualitative comparative analysis, Journal of Business Research 69(4): 1329-1332. https://doi.org/10.1016/j.jbusres.2015.10.101

Wetzels, M.; Odekerken-Schröder, G.; Van Oppen, C. 2009. Using PLS path modeling for assessing hierarchical construct models: guidelines and empirical illustration, MIS Quarterly 33(1): 177-195. https://doi.org/10.2307/20650284

Wong, D. 2013. Brand Evangelists. Available from Internet: https://www.cision.com/us/2013/08/state-of-marketing-videobrand-evangelists

Woods, D. D. 2015. Four concepts for resilience and the implications for the future of resilience engineering, Reliability Engineering \& System Safety 141: 5-9. https://doi.org/10.1016/j.ress.2015.03.018

Xiong, L.; King, C.; Piehler, R. 2013. “That's not my job”: exploring the employee perspective in the development of brand ambassadors, International Journal of Hospitality Management 35: 348-359. https://doi.org/10.1016/j.ijhm.2013.07.009 